\title{
ANALISIS NARATIF: KEMISKINAN DALAM PROGRAM REALITY TV "PEMBERIAN MISTERIUS" DI STASIUN SCTV
}

\author{
Lilik Kustanto \\ Jurusan Televisi, Fakultas Seni Media Rekam, ISI Yogyakarta \\ Jln. Parangtritis Km 6,5 Bantul, Yogyakarta \\ No.HP.087828168395,E-mail: elbaraja9@gmail.com
}

\begin{abstract}
ABSTRAK
Reality TV merupakan sebuah program televisi yang menggambarkan sebuah peristiwa realita atau peristiwa nyata. Namun, program tersebut mengalami perkembangan dengan menampilkan kejadian yang nyata dan dibuat sehingga disebut program hibriditas. Sebagai sebuah program yang menggambarkan kejadian tentunya reality TV memiliki aspek narasi di dalamnya. Salah satunya adalah program reality TV "Pemberian Misterius" yang menarasikan tentang memberi pertolongan dengan memberi hadiah kepada orang lain yang memenuhi kriteria yang ditetapkan. Namun, narasi yang ceritakan tersebut sebenarnya memiliki makna lain sebagai sebuah representasi kemiskinan yang secara implisit tidak terbaca oleh penonton. Analisis naratif merupakan metode mengkaji narasi yang dapat membantu kita untuk memahami, mengevaluasi dan memaknai struktur narasi. Oleh sebab itu program reality TV "Pemberian Misterius" akan dianalisis menggunakan analisis naratif untuk melihat makna sebenarnya, yaitu representasi kemiskinan dalam program reality TV "Pemberian Misterius".
\end{abstract}

Kata kunci: reality TV, reality TV "Pemberian Misterius", analisis naratif, representasi kemiskinan

\section{ABSTRACT}

Poverty in Reality TV Programme "Mysterious Gift" on SCTV Television Channel. Reality $T V$ is a television program which depicts a realistic event or real event. However, the program evolves and depicts real (unscripted) and manufactured events (scripted), so that it's called hybrid program. As a program which depicts events, reality TV contains narration aspect. One of them is reality TV program called "Pemberian Misterius" which narrates the aids delivery by giving gifts to others who meet established criteria. However, the narration contains another meaning which is as an implicit representation of poverty the audience isn't aware of. Narrative analysis is the method of reviewing narration which can help us to understand, evaluate and interpret narration. Therefore, "Pemberian Misterius" reality TV program was analyzed using narrative analysis to discover its meaning, which is representation of poverty in "Pemberian Misterius" reality TV program.

Keywords: reality TV, Reality TV "Pemberian Misterius", narative analisys, representation of poverty

\section{PENDAHULUAN}

Menjamurnya program reality $\mathrm{TV}$ yang populer disebut reality show di Indonesia memberikan nilai tersendiri bagi industri televisi di Indonesia. Kehadiran program tersebut memberikan alternatif pilihan program tayangan bagi penonton televisi. Program reality show di Indonesia tidak lepas dari perkembangan reality TV di luar negeri, salah satunya di Amerika. Reality TV mengalami perkembangan pesat di Amerika pada awal tahun 1990-an. Awalnya program tersebut 
merupakan sebuah program yang dikategorikan dalam program yang menyilangkan program faktual dan fiksi. Istilah awal untuk program tersebut adalah factual entertainment programme. Merujuk Hill (2005:14), bahwa program-program tersebut dikategorikan dalam program faktual populer televisi yang lazim disebut 'factual entertainment'. Kategori ini mengindikasikan persilangan antara program faktual seperti news atau dokumenter dengan program fiksi (soap opera atau game show). Lebih jauh dikatakan sebagai program hibriditas genre, yaitu program yang memiliki percampuran atau pencangkokan genre, antara fiksi dan nonfiksi.

Dalam sejarah perkembangannya, program reality TVjugatidak lepas daripengaruh yang sangat kuat oleh munculnya tabloid jurnalistik di Amerika dan program dokumenter televisi pada masa itu. Tabloid dikemas dalam bentuk informasi dan entertainment yang memiliki kesamaan dengan reality $\mathrm{TV}$, yaitu hibriditas bentuk (form) dan isi (content), yang secara tidak langsung memiliki relevansi dan berpengaruh terhadap penonton reality TV dan keberadaan reality TV itu sendiri. Pada sisi lain, program dokumenter televisi juga memiliki kontribusi yang kuat terhadap kemunculan reality TV. Program dokumenter yang merupakan esensi dasar dari program faktual merupakan embrio dari format yang diadopsi dan dikembangkan hingga kemunculan bentuk reality TV. Program dokumenter jurnalistik, dokumenter realis, dokumenter observasional (direct cinemal cinema verite), dokumenter performatif, doku-drama dan mock documenter cukup berpengaruh pada masa itu.

Istilah reality $\mathrm{TV}$ muncul dan mulai dikenal pada tahun 1990-an yang diawali dengan munculnya reality TV 'Crime and Emergency
Services'. Ditandai juga dengan hadirnya program 'infotainment' tentang perjalanan dari Amerika ke Eropa. Pada awal kemunculannya, program reality TV lebih banyak dipengaruhi dengan kejadian yang real atau peristiwa yang benar-benar terjadi dan dikemas dengan bentuk yang dapat menghibur. Dalam proses perkembangannya, program reality TV mengalami berbagai bentuk perkembangan yang begitu kompleks hingga muncul berbagai varian dari tipe reality TV, seperti game show, dating, social experiment, dan selfimprovement. Lebih jauh Hill menjelaskan dalam bukunya bahwa:

"Reality TV is about the
development of a television genre
often called reality TV. Reality TV
is catch-all category that includes
a wide range of entertainment
programmes about real people".
Sometimes called popular factual
television, reality TV is located
in border territories, between
information and entertainment,
documentary and drama" (Hill,
2005:2).

Reality TV merupakan pengembangan dari genre dalam program televisi yang sebelumnya disebut factual entertainment sebagai bagian dari program faktual yang populer. Merupakan persilangan ataupun pencangkokan (hibriditas) dari program faktual dan fiksi. Reality TV juga memiliki wilayah yang dekat dengan nilai-nilai sosial dan nilai hiburan. Bentuk percampuran yang terkadang sangat kabur batasannya ini menjadikan program reality TV sekilas lebih nampak sebagai sebuah program "real atau realita" dibandingkan sebagai program fiksi/scripted programme, bahkan hibriditas genre tersebut kadang tersamarkan dan lebih menyerupai program dokumenter. Terlepas dari hal tersebut, 
bagian yang cukup menarik dalam program reality TV adalah objek yang dimunculkan lebih banyak bersinggungan dengan wilayah fenomena sosial atau kehidupan masyarakat. Dengan demikian, objek penceritaan di dalam sebuah program reality TV kadang menjadi khas dengan wilayah produksi maupun wilayah penayangan/target penontonnya. Merujuk pernyataan tentang reality TV yang berhubungan dengan wilayah sosial adalah dari Richard Kilborn yang menyatakan sebagai berikut:

The primary aim of much reality programming is 'that of diversion rather enlightment'; and although some makers of reality programmes argue that certain formats can provide social value, it is the case that the reality genre as a whole is designed for entertainment value (Kilborn, 2003:11).

Reality TV sebagai sebuah program televisi dapat dilihat sebagai sebuah program yang merepresentasikan realitas dan juga sebagai sebuah program yang memproduksi makna. Dalam hal ini program reality $\mathrm{TV}$ dapat dilihat pada dua sisi atau perspektif yang berbeda. Program reality TV merupakan bentukan atau ciptaan sebuah institusi media yang memiliki bagian dalam produksi praktik budaya yang lebih berkait pada ekonomi politik, juga dapat dilihat sebagai sebuah teks budaya yang memproduksi makna-makna. Kedua fokus perspektif ini menjadi orientasi yang menarik untuk menguak dimensi-dimensi fenomena atau realitas sosial suatu masyarakat melalui program reality $\mathrm{TV}$.

Pemilihan perspektif kedua yang menempatkan program reality $\mathrm{TV}$ sebagai teks yang memproduksi makna, baik makna yang berasal dari realitas empiris maupun yang diciptakan oleh media yang menganggap realitas media sebagai bentukan makna yang berasal dari masyarakat, baik karena bersifat imperatif dari faktor-faktor yang berasal dari masyarakat, maupun berasal dari orientasi budaya pelaku media. Dari sini program reality TV dilihat pada satu sisi sebagai instrumen dari kekuasaan (ekonomi dan/ atau politik) dengan memproduksi budaya dominan untuk pengendalian (dominasi dan hegemoni) masyarakat dan pada sisi lain dilihat sebagai institusi yang memiliki otonomi dan independensi dalam memproduksi budaya dalam masyarakat. Oleh sebab itu, perlu kritisisme yang diarahkan pada transformasi sosial yang dibentuk ataupun terkandung dalam program reality $\mathrm{TV}$.

Di Indonesia, reality TV lebih dikenal dengan istilah reality show (peneliti memilih menggunakan istilah reality $\mathrm{TV}$ daripada reality show) menjadi program yang populer seiring dengan banyak berdirinya stasiun televisi nasional. Tantangan kompetisi antarstasiun televisi untuk memberikan tayangan yang bervariasi dan menarik semakin menguatkan kehadiran program reality TV dengan berbagai variannya di Indonesia. Dari varian program games, dating, hingga social experiment begitu marak mengisi layar kaca. Semaraknya tayangan reality TV di stasiun televisi dengan berbagai tipe atau variannya tidak hanya memberi warna pada siaran program, namun juga memperlihatkan begitu ketatnya persaingan di antara stasiun televisi untuk menarik perhatian penonton.

Pada sekitar tahun 2010, program reality $\mathrm{TV}$ menjadi program yang tren bagi stasiun-stasiun televisi swasta nasional. Hampir sebagian besar stasiun televisi swasta nasional (RCTI, SCTV, ANTV, TransTV, dan lainnya) 
memiliki program reality TV unggulan masingmasing seperti "Tolong", "Bedah Rumah", "Pemberian Misterius", "Termehek-mehek", dan "Uang Kaget". Dengan demikian, tayangan program reality TV semarak menghiasi layar kaca televisi di Indonesia. Akibat semaraknya tayangan reality $\mathrm{TV}$ tersebut tanpa disadari telah menggiring penonton televisi menonton dan menggandrungi tayangan tersebut.

Program reality TV yang tren pada saat itu lebih banyak menampilkan kehidupan orang miskin ("Tolong", "Bedah Rumah", "Pemberian Misterius", "Uang Kaget”). Penampilan tersebut diharapkan dapat memancing rasa iba dan simpati penonton baik terhadap objek program maupun subjek program yang terkesan sebagai penolong kaum miskin. Tontonan tersebut semakin menarik perhatian karena didukung dengan pengambilan gambar yang langsung dengan teknik pengambilan gambar sedemikian rupa yang seakan-akan menggambarkan realitas sebenarnya. Realitas yang ada di dalam tayangan reality $\mathrm{TV}$ tersebut seakan merupakan kenyataan yang mampu menarik simpati dan empati penonton. Ironisnya, para penonton terutama masyarakat menengah ke bawah yang sangat awam dengan dunia pertelevisian tidak menyadari bahwa program acara reality $\mathrm{TV}$ tersebut tidaklah lebih menguntungkan stasiun televisi karena masyarakat miskin menjadi bahan eksploitasi atau objek yang menjalankan keberhasilan sebuah program. Fenomena inilah yang menjadikan realitas di dalam program reality TV merupakan realitas semu yang menjadikan masyarakat miskin sebagai objek yang dieksploitasi.

Salah satu program reality $\mathrm{TV}$ yang menarik untuk dikaji adalah program reality $\mathrm{TV}$ "Pemberian Misterius" (PM) yang disiarkan oleh stasiun televisi SCTV. Program reality TV
"Pemberian Misterius" ditayangkan setiap hari Sabtu pada pukul 17.30 - 18.30 WIB pada tahun 2010. Reality TV ini termasuk dalam kategori social experiment, yaitu tema besar dalam cerita berhubungan dengan kehidupan masyarakat berikut nilai-nilai sosial di dalamnya. Reality TV "Pemberian Misterius" mengisahkan seorang tokoh yang akan memberikan bantuan kepada seseorang namun melalui orang lain (sebagai target utama). Dalam mencari target utama ada proses pengujian dan seleksi dengan beberapa kriteria yang telah ditetapkan dalam program tersebut. Format program reality TV ini merupakan percampuran dari scripted dan unscripted programme. Kerangka cerita sudah dibuat dalam naskah dengan memilih tokoh pemeran yang kemudian secara acak akan mencari dan menyeleksi target utamanya. Tema besar dalam reality TV ini secara mendasar adalah memberikan bantuan cuma-cuma kepada orang lain yang memiliki kelas ekonomi bawah.

Sebuah cerita tidak mungkin lepas dari unsur naratif. Sebuah cerita pasti memiliki unsur-unsur seperti tokoh, masalah, konflik, lokasi, dan waktu (Pratista, 2008:2). Demikian halnya di dalam program reality TV PM, unsur cerita menjadi bagian yang melekat. Dengan kata lain, reality TV PM juga memiliki unsur naratif, sehingga secara sederhana dapat disebut sebagai sebuah teks naratif. Penulis akan melihat lebih jauh dalam analisis ini untuk menjelaskan lebih rinci bahwa program reality ini sebagai sebuah teks naratif melalui beberapa konsep. Peneliti berusaha memahami, mengevaluasi, dan menganalisis program reality TV PM dengan melihat sistem narasi di dalamnya. Analisis naratif dipilih sebagai metode yang tepat dalam penelitian ini dikarenakan analisis tersebut akan membantu dalam menjelaskan sistem narasi dan memaknai narasi yang mendasarinya. 
Permasalahan yang dihadapi masyarakat penonton terhadap tayangan reality TV PM adalah interpretasi mereka yang akan melihat permukaan program, yaitu program yang memiliki nilai kemanusiaan, memberikan bantuan cuma-cuma dan menggambarkan adanya kejujuran, keikhlasan sosok-sosok tokoh di dalam program. Penyerapan makna permukaan tersebut menjadi berbalik kebenarannya apabila program tersebut dapat dimaknai secara mendalam halhal implisit yang tidak pernah dinyatakan dalam cerita dan plot-plot program tersebut. Lebih jauh, mengamati secara mendalam program reality $\mathrm{TV}$ PM bertujuan untuk mengamati, mengevaluasi, dan menganalisis sebuah teks naratif untuk menjelaskan bangunan struktur narasinya. Secara lebih khusus tujuan ini diharapkan untuk melihat lebih mendalam tema kemiskinan melalui narasi yang diciptakan dalam program reality TV PM.

Penelitian ini secara akademis diharapkan dapat memberikan penjelasan dan pemahaman tentang pembacaan struktur narasi dapat digunakan untuk membongkar realitas TV melalui analisis teks. Dengan demikian, secara praktis dapat memberikan pemahaman bahwa melalui struktur narasi yang dibangun dapat memberi pengetahuan tentang reality $\mathrm{TV}$ tidaklah sama dengan realitas sesungguhnya dan ada kepentingan lain di balik program tersebut seperti adanya komodifikasi, eksploitasi, dan objektivikasi terhadap kemiskinan. Secara umum, penelitian ini diharapkan dapat memberikan pengetahuan kepada masyarakat bahwa di balik teks sebuah tayangan reality TV muncul adanya keuntungan lebih pada pihak produsen atau institusi produksi dan penyiar program reality TV dibanding dengan masyarakat yang menjadi bagian di dalam program reality $\mathrm{TV}$.

\section{METODOLOGI PENELITIAN}

Analisis naratif sebagai metode dalam penelitian ini digunakan untuk membantu memahami, menganalisis, dan mengevaluasi sebuah kisah. Penelitian ini menggunakan metode analisis naratif yang dikembangkan oleh beberapa ahli seperti Tzvetan Todorov dengan struktur narasinya, Vladimir Propp dengan fungsi karakter dalam narasi, story dan plot, Levi Strauss dengan oposisi biner dalam narasi, dan Mieke Bal tentang sebuah teks naratif dengan tiga lapisan yang mendasarinya, yaitu lapisan teks, story (cerita), dan fabula. Namun, dalam artikel ini akan dipaparkan hanya salah satu metode pembacaan teks naratif, yaitu melalui “oposisi biner dalam narasi” (Levi Strauss).

Sebuah catatan, bahwa analisis naratif berusaha membuat pernyataannya, yang terdiri atas berbagai macam teks narasi yang dibuat untuk berbagai macam tujuan dan melayani berbagai macam fungsi yang berbeda sehingga ada corpus (tubuh) yang ditetapkan terlebih dahulu. Untuk membatasi corpus tersebut, perlu formulasi karakteristik yang dapat membantu membatasi corpus dari analisis. Formulasi karakteristik penelitian ini adalah sebuah program televisi (audiovisual) yang dapat dibaca sebagai sebuah teks naratif melalui struktur naratifnya. Karakteristik yang penting dalam program televisi tersebut harus didefinisikan untuk menjadi titik tolak pada fase berikutnya, yaitu sebuah deskripsi atas cara di mana setiap teks naratif dikonstruksi. Pada proses ini akan dapat dipahami sistem narasi yang berlaku dalam sebuah teks naratif. Selanjutnya dapat meneliti variasi yang mungkin terjadi apabila sistem narasi tersebut dikonkretkan ke dalam sebuah teks naratif. Langkah terakhir ini dapat diasumsikan bahwa jumlah tidak terbatas teks naratif dapat 
dideskripsikan dengan menggunakan jumlah konsep terbatas yang terkandung di dalam sistem narasi. Sedikit penyederhanaan yang dilakukan dalam makalah ini yang membongkar "struktur dalam" program reality TV PM untuk membaca tema kemiskinan yang dinarasikan di dalam program tersebut.

Sistem narasi yang ada dalam sebuah teks naratif akan diformulasikan secara sistematis sehingga diharapkan dapat membantu untuk mendeskripsikan sebuah teks naratif. Deskripsi teks naratif tersebut akan membantu pemahaman lebih mendalam atas sebuah teks, dampak dan ideologi yang dibawa secara implisit dalam sebuah teks naratif. Metode ini akan membantu pembaca/ penonton dan peneliti untuk mengungkap secara sistematis mengenai cara bagaimana teks naratif tersebut dikonstruksi dan menyingkap makna-makna yang tidak dimunculkan secara eksplisit.

Desain dalam penelitian ini adalah mengasumsikan program reality TV PM sebagai sebuah teks naratif. Asumsi tersebut akan dibuktikan dengan menggunakan pendekatan pada tiga kriteria, yaitu dua tipe pembicara, lapisan teks, cerita, dan fabula, serta 'isi' yang disampaikan kepada pembaca, adalah serangkaian kejadian yang saling berhubungan yang dihasilkan atau dialami oleh aktor yang dipresentasikan menurut cara tertentu. Penjelasan program reality TV sebagai sebuah teks naratif tidak dibahas di dalam artikel ini.

Peneliti akan menganalisis program tersebut tidak melalui medium audiovisual secara langsung, namun mentransformasikan bentuk audiovisual tersebut dalam bentuk teks kebahasaan. Program audiovisual akan ditransformasikan menjadi sebuah teks yang disebut dengan sinopsis dan di-breakdown dalam bentuk treatment. Langkah ini semata hanya untuk mempermudah dalam membaca, memahami, dan menganalisis objek kajian bukan untuk membuat batasan. Oleh karena itu, kegiatan awal menonton karya audiovisual secara utuh tetap dilakukan kemudian membreakdown ke dalam bentuk teks kebahasaan, yaitu sebuah sinopsis dan treatment. Langkah selanjutnya adalah pembuktian dengan konsep yang mendasari sebuah teks naratif. Dengan demikian, analisis program reality TV PM disebut sebagai analisis teks naratif.

Seperti dalam judul, kemiskinan dalam program reality TV Pemberian Misterius tidaklah eksplisit terlihat dan terbaca oleh penonton dikarenakan tersamarkan dengan cerita dan kisah di dalam program yang memberikan pertolongan atau hadiah cumacuma kepada masyarakat yang dianggap kekurangan secara ekonomi. Tema kemiskinan tidak terwujud secara langsung, namun akan dapat terlihat setelah dibaca lebih mendalam dengan metode analisis naratif.

\section{Naratif}

Reality TV PM merupakan sebuah program yang dibangun melalui cerita di dalamnya. Dari urutan adegan demi adegan, tema yang diambil, lokasi dalam kisah, ruang dan waktu, tokoh yang muncul, karakter yang dibangun, alur, konflik, dan tujuan cerita merupakan unsur-unsur naratif. Naratif adalah suatu rangkaian peristiwa yang berhubungan satu sama lain dan terikat oleh logika sebabakibat (kausalitas) yang terjadi dalam satu ruang dan waktu (Pratista, 2008:33). Naratif adalah penjelasan yang bertata urut yang mengklaim sebagai rekaman peristiwa. Naratif merupakan bentuk terstruktur di mana kisah membuat penjelasan tentang bagaimana dunia ini (Barker, 2008:3). 
Prince (2003:58) dalam Dictionary of Narratology menjelaskan bahwa, "narrative is the representation (as a product and procces, object and act, structure and structuration) of one or more real or fictive EVENTS communicated by one, two, or several (more or less overt) NARRATEES". Onega dan Landa dalam Herman \& Vervaeck (2005:13) mendefinisikan naratif sebagai berikut. " $A$ narrative is the semiotic representation of a series of events meaningfully connected in a temporal and causal way."

Disebutkan juga bahwa naratif berkaitan erat dengan hubungan sebab-akibat dari sebuah rangkain cerita. "Narratives are based on cause-and-effect relationships that are applied to sequences of events" (Fludernick, 2009:2).

Sebagaimana dikatakan Stam (1992:69), "Narrative can be understood as a recounting of two or more events (or situation and an event) that are logically connected, occur over time, and are linked by a consistent subjek into a whole."

Dengan demikian, sebuah naratif tentunya memiliki hubungan atau relasi yang terjalin secara logis yang dihubungkan oleh keberadaan subjek dalam cerita tersebut. Pendapat lain yang menguatkan pendapat tersebut menyatakan, bahwa "A narrative is integral to the process of storytelling" (Casey et al., 2002:100). Bahwa naratif merupakan bagian yang berhubungan secara utuh tidak terpisahkan dengan proses penceritaan. Sebagaimana dalam program Reality TV PM yang memiliki hibriditas format, yaitu menggunakan bentuk fiksi dan non-fiksi, memiliki unsur naratif di dalamnya.

\section{Analisis Naratif}

Stok (2007:73) menyatakan bahwa analisis naratif adalah sebuah cara yang kuat dan bermanfaat untuk menjelajahi teks-teks media. Oleh sebab itu, analisis naratif kerap digunakan untuk membongkar maksud ideologis sebuah karya yang tersembunyi di baliknya. Selanjutnya Greimas (http://www.cla.purdue.edu/English/ theory/narratology/modules/greimasplot.html diakses pada tanggal 1 Desember 2009 pukul 12.55 WIB) menyatakan bahwa: The study of narrative is particularly important since our ordering of time and space in narrative forms constitutes one of the primary ways we construct meaning in general. Studi naratif sangatlah penting dalam membaca makna yang dikonstruksi dalam sebuah teks. Analisis naratif lebih jauh dikatakan Robert Stam bahwa:

"Like all semiotic inquiry, narrative analysis seeks to peel away the seemingly "motivated" and "natural" relationship between the signifier and the story-world in order to reveal the deeper system of cultural associations and relationships that are expressed through narrative form" (1992:69).

Analisisnaratifdalamperkembangannya tidak hanya menjadi sebuah kajian yang kaku terhadap teks, namun memiliki hubungan yang sangat erat dengan analisis budaya (cultural analysis) atau yang disebut juga cultural studies. Mieke Bal dalam bukunya Narratology menjelaskan keterkaitan naratologi dengan wilayah culture studies atau yang lebih suka ia sebut sebagai 'cultural analysis.' Bal (1997:220) menyatakan bahwa 'I would like to offer, by way of conclusion, some thoughts about relation of narratology to what has been called 'cultural studies' but what I prefer call 'cultural analysis.

Selanjutnya Bal, menyatakan: instead, narrative is a cultural attitude, hence, narratology a perspective on 
culture.'

'What I propose we are best off with in the age of cultural studies is aconception of narratology that implicates text and reading, subject and object, production and analysis, in the act of understanding. In other words, I advocate a narrative theory enables the differentiation of the place of narrative in any cultural expression without privileging any medium, mode, or use; that differentiates its relative importance and the effect of the narrative (segments) on the remainder of the object as well as on the reader, listener, viewer. A theory, that is, which defines and describes narrativity, not narrative; not a genre or object but a cultural mode of expresson", (1997:220).

Analisis naratif merupakan sebuah metode analisis dari narasi, narasi teks, gambargambar, pertunjukan, kejadian; artefak kultural yang 'menceritakan sebuah kisah'. Analisis ini membantu untuk memahami, menganalisis, dan mengevaluasi narasi. Analisis naratif adalah analisis mengenai narasi, baik narasi fiksi (novel, pusi, cerita rakyat, dongeng, film, komik, musik dan sebagainya) ataupun fakta (Eriyanto, 2013:9).

\section{Narasi dan Oposisi Biner Levi Strauss}

Dalam sebuah teks naratif selalu terdapat struktur narasi. Struktur narasi tersebut merupakan struktur luar, yang hanya bisa dilihat secara eksplisit apa yang dimunculkan dalam narasi seperti situasi awal, gangguan, dan kondisi akhir dari narasi. Selain struktur luar, ada bagian yang disebut struktur dalam. Struktur dalam merupakan struktur yang tidak eksplisit nampak, dan hanya dapat dibaca atau dilihat saat dilakukan analisis. Salah satu metode untuk mengetahui struktur dalam tersebut menggunakan metode yang diperkenalkan oleh Levi Staruss, yaitu tentang oposisi biner.

Oposisi biner yang diperkenalkan oleh Levi Strauss membahas adanya perbedaan di dalam sebuah teks narasi. Pembacaan awal dari oposisi biner melalui pemecahan teks seperti layaknya sebuah kata atau kalimat (kebahasaan). Levi Strauss menggunakan dua konsep penting dari Saussure, yaitu pembedaan dan konsep sintagmatik dan paradigmatik. Konsep sintagmatik merupakan pembacaan hubungan antara satu tanda dengan tanda lain dalam satu kesatuan yang linear. Dalam sebuah teks narasi reality TV PM tanda tersebut dapat dibaca dalam bentuk pemecahan synopsis atau bagian di dalam treatment ataupun pengurutan kejadian-kejadian. Di mana urutan kejadian-kejadian tersebut saling memiliki relasi yang terhubung. Seperti sebuah scene dengan scene lainnya dalam satu teks narasi, memiliki hubungan atau relasi. Adapun konsep paradigmatik merupakan relasi antara tandatanda dalam suatu paradigma (kesamaan umum): unit-unit memiliki kesamaan karakteristik yang menentukan keanggotaannya alam paradigma tersebut (Ahimsa-Putra, 2013:162).

\section{Konsep Kemiskinan}

Kemiskinan sesungguhnya merupakan masalah sosial yang jauh lebih kompleks daripada sekadar persoaan pendapatan yang dimiliki sebagai aset untuk kelangsungan hidup. Kemiskinan atau lebih tepat disebut perangkap kemiskinan selain berkaitan dengan ketidakmampuan sebuah keluarga untuk memenuhi kebutuhan hidup sehari-hari, juga menyangkut kerentanan, ketidakberdayaan, keterisolasian, dan kelemahan jasmani. 
Klasifikasi masyarakat miskin masih memiliki berbagai macam ukuran yang digunakan dalam menentukan seseorang atau sekelompok orang disebut miskin. Namun, ada beberapa ciri kemiskinan yang dapat digunakan sebagai alat ukur klasifikasi kemiskinan, yaitu:

a. Masyarakat yang hidup di bawah garis kemiskinan pada umumnya tidak memiliki faktor produksi sendiri, seperti tanah, modal, ataupun keterampilan. Faktor produksinya sedikit sehingga kemampuan untuk memperoleh pendapatan sangatlah terbatas.

b. Pada umumnya tidak memiliki kemungkinan memperoleh aset produksi dengan kekuatan sendiri.

c. Tingkat pendidikan golongan miskin pada umumnya rendah, bahkan tidak sampai tamat sekolah dasar. Hal tersebut banyak dipengaruhi faktor ekonomi di mana mereka menghabiskan waktu untuk mencari nafkah sehingga tidak mempunyai waktu untuk belajar.

d. Banyak yang tinggal di pedesaan dan tidak memiliki tanah garapan. Pada umumnya bekerja sebagai buruh, petani penggarap ataupun pekerja kasar.

e. Banyak di antara mereka tinggal dan hidup di kota dan berusia muda dan tidak mempunyai keterampilan dan pendidika sehingga tidak memiliki daya saing keterampilan sebagai tenaga kerja. Rata-rata hanya sebagai buruh rendahan atau berusaha melakukan usaha, namun memiliki kemampuan produksi yang rendah sehingga tidak memiliki penghasilan yang memadai dan selalu memiliki masalah ekonomi.
Dalam reality TV PM, target yang menjadi sasaran pencarian dan yang mendapatkan hadiah atau pemberian pertolongan dalam program merupakan orang-orang yang memiliki masalah ekonomi. Rata-rata mereka adalah penduduk kota yang memiliki pekerjaan berbekal tenaga (tenaga kasar) tanpa memiliki keterampilan atau keahlian yang menjadikan posisi saing dalam pekerjaan mereka. Mereka tidak memiliki faktor produksi dan keterampilan sehingga tidak mampu memiliki atau mendapatkan aset produksi dengan modal sendiri.

\section{PEMBAHASAN}

Membaca Narasi yang Diciptakan Reality TV PM Menggunakan Oposisi Biner dalam Narasi (Levi Strauss)

Pengamatan terhadap teks narasi program reality TV PM akan memperlihatkan beberapa oposisi biner, terutama dalam penggambaran tokoh Ibu Sulastri, Pemberi Hadiah Misterius dengan sosok Ibu Rini Nurhayati dan Ibu Puji Rahayu sebagai penerima bantuan (lihat lampiran; sinopis).

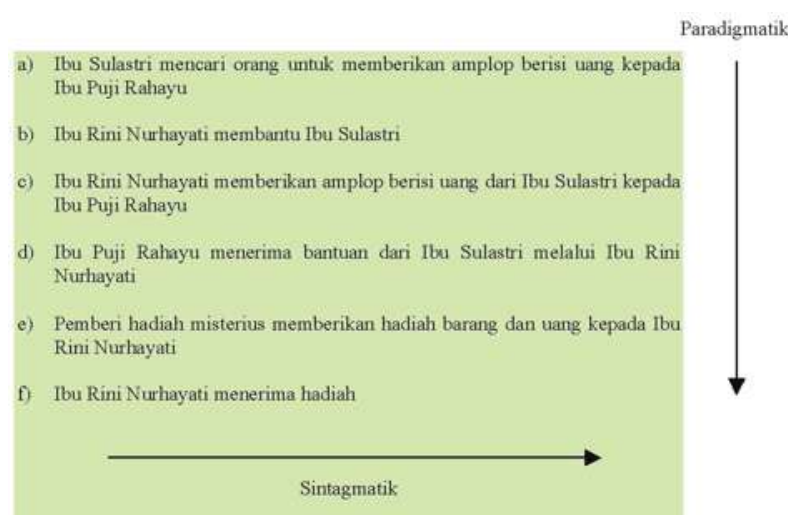

Penjelasan:

Pembagian tokoh dan karakter di atas merupakan agen-agen pencerita baik agen pencerita utama maupun pendukung di dalam program reality TV PM. Pembagian tokoh dan karakter dibaca melalui synopsis maupun pengamatan audio visual tayangan program reality TV PM. Pembagian lain yang telah dlakukan adalah dengan pembacaan karakter dan fungsi tokoh dalam sebuah teks naratif merujuk pada Vladimir Propp. 
Dalam pengamatan oposisi biner ini terlebih dahulu diawali dengan menyusun miteme (kata, kalimat) yang selanjutnya menyusun miteme tersebut dalam bentuk sintagmatik dan paradigmatik. Susunan miteme secara sintagmatik disusun secara horizontal, sedangkan paradigmatik secara vertikal. Penyusunan miteme dalam reality TV PM akan dilihat melalui scene-scene utama cerita yang memiliki relasi kemudian menyusun secara sintagmatik dan paradigmatik.

Penyusunan miteme-miteme tersebut dalam susunan sintagmatik, dipilih berdasarkan dari adanya relasi di antara miteme-miteme tersebut. Relasi tersebut berkaitan dalam adegan, dialog, dan karakter yang dimunculkan di dalam reality TV PM. Selanjutnya akan terlihat oposisi berlawanan (oposisi biner) dari masing-masing adegan dan karakter tersebut.

Pembagian yang penting dalam analisis ini adalah karakter yang dibedakan dalam dua kelompok, yaitu pemberi hadiah/bantuan sebagai kelompok pahlawan dan yang ditolong atau penerima bantuan/hadiah. Ibu Sulastri dan Pemberi hadiah Misterius menjadi kelompok pahlawan (hero) yang memiliki kemampuan untuk menolong orang lain (Ibu Rini Nurhayati dan Ibu Puji Rahayu). Sementara itu, kelompok satunya adalah Ibu Rini Nurhayati dan Ibu Puji Rahayu sebagai kelompok penerima hadiah/ pertolongan. Ibu Sulastri dan Pemberi Hadiah Misterius memiliki kesamaan karakter dan posisi dalam reality TV, sedangkan Ibu Rini Nurhayati dan Ibu Puji Rahayu juga memiliki persamaan posisi karakter di antara mereka.
Melalui kejadian tersebut dapat dibuat pengelompokan tokoh sebagai berikut:

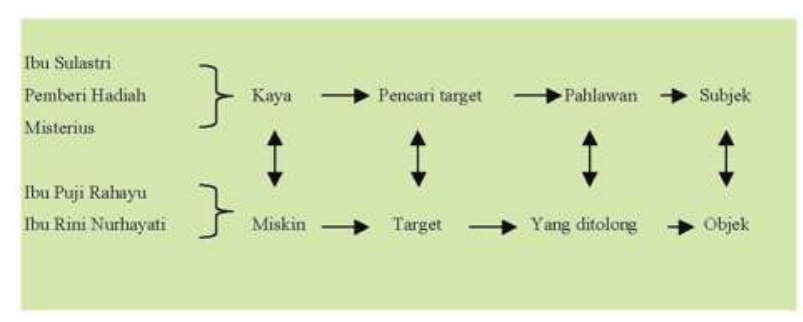

Selanjutnya pembacaan secara paradigmatik dapat menjelaskan bahwa dari pengelompokan yang memiliki relasi tersebut di atas dapat dibaca jelas adanya perbedaan (oposisi biner) di antara kedua kelompok. Sosok Ibu Rini Nurhayati digambarkan sebagai sosok yang mau membantu Ibu Sulastri dengan ikhlas mengantarkan amplop uang kepada Ibu Puji Rahayu. Ibu Rini Nurhayati juga digambarkan sebagai masyarakat golongan ekonomi lemah yang memiliki masalah ekonomi. Demikian halnya dengan Ibu Puji Rahayu digambarkan sebagai sosok yang memiliki masalah ekonomi terutama untuk membiayai perawatan anaknya yang dirawat di rumah sakit. Dari kelompok ini dapat digambarkan sebagai kelompok miskin yang memiliki masalah ekonomi dan memerlukan bantuan dari orang lain. Sementara itu, kelompok Ibu Sulastri dan Pemberi Hadiah Misterius digambarkan sebagai sosok pahlawan yang memiliki kemampuan untuk membantu orang lain. Melalui Ibu Rini Nurhayati, Ibu Sulastri memberikan bantuan kepada Ibu Puji Rahayu. Selanjutnya, melalui Pemberi Hadiah Misterius, Ibu Puji Rahayu memberikan hadiah kepada Ibu Rini Nurhayati.

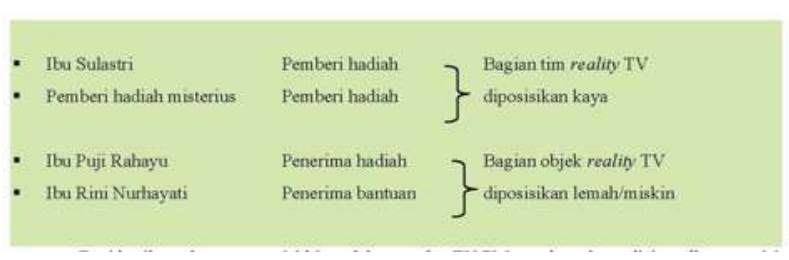


Dari hasil pembacaan oposisi biner dalam reality TV PM tersebut, dapat disimpulkan oposisi biner yang muncul secara nyata (eksplisit) adalah adanya pemberi hadiah dan yang menerima hadiah. Reality TV PM nampak sebagai program yang menggambarkan adanya kebaikan dari sosok pahlawan yang mampu memberikan bantuan atau menolong orang lain yang membutuhkan. Kehadiran Ibu Sulastri dan Pemberi Hadiah Misterius menjadi gambaran adanya orang-orang mampu/kaya yang peduli kepada orang lain yang punya masalah ekonomi. Namun, secara abstrak reality $\mathrm{TV}$ PM dapat dibaca dengan adanya oposisi biner antara kaya dan miskin dan adanya subjek dan objek yang bermetafora dengan gambaran kepahlawanan. Kehadiran dari sosok pahlawan menggambarkan adanya kemampuan dari golongan mampu secara ekononomi (kaya) yang memiliki kekuatan untuk membantu kaum lemah (miskin). Namun, pada sisi ini golongan Ibu Rini Nurhayati dan Ibu Puji Rahayu menjadi objek yang menerima hadiah dan objek yang menjadi bagian penting dalam narasi. Narasi reality TV PM dibangun sedemikian rupa dengan menempatkan Ibu Rini Nurhayati dan Ibu Puji bukan sebagai penerima hadiah atau yang ditolong namun menjadi bagian penting narasi dan dapat melabelkan sosok pahlawan kepada Ibu Sulastri dan Pemberi Hadiah Misterius. Adanya kelompok oposisi biner miskin merupakan bagian yang dapat menggerakkan narasi reality TV PM sehingga reality TV PM memiliki gambaran kebaikan, kepahlawanan, kepedulian yang dimunculkan secara eksplisit dalam tayangan program.

Dari pembacaan oposisi biner tersebut, Reality TV PM merupakan teks narasi yang mengisahkan dua orang dermawan yang menjadi pahlawan bagi orang-orang yang ditolongnya dengan diberi hadiah uang ataupun dengan barang. Dua orang tersebut adalah sosok Ibu Sulastri yang mencari target yang akan mendapatkan hadiah. Penampilan Ibu Sulastri yang terkesan sederhana, berkursi roda, dan kebingungan mencari orang yang diharapkan membantu mendorong kursi rodanya untuk mengantar ke rumah sakit Tugu. Penampilan yang mencitrakan orang biasa, namun yang memiliki kedermawanan dan menjadi pahlawan bagi orang lain. Ibu Sulastri berperan mencari target orang yang akan diberi hadiah. Dalam pencarian target selalu mensyaratkan yang mau membantunya dengan ikhlas dan dilihat dari sisi ekonomi memiliki kelas atau golongan bawah. Sosok pahlawan yang lain adalah Pemberi Hadiah Misterius yang kemunculannya di akhir cerita dengan tiba-tiba mendatangi target yang sudah memenuhi syarat atau kriteria untuk memberikan hadiah. Penampilan sosok tersebut yang berkesan "parlente" dengan pakaian berjas, bermobil dengan seorang supir yang menggambarkan identitas golongan kaya yang sukses dan memiliki hati mulia, yaitu kedermawanan, memberikan hadiah kepada orang yang membutuhkan.

Di sisi lain, sosok karakter Ibu Rini Nurhayati dan Ibu Puji Rahayu merupakan sosok target yang menjadi penggambaran sosok yang lemah, kelas bawah dengan permasalahan ekonominya, dan masih memiliki semangat kerja juga semangat membantu orang lain tanpa pamrih (ikhlas). Dengan demikian, program reality TV ini berfokus pada adegan ketulusan menolong orang lain akan mendapatkan imbalan tidak terduga (misterius) dengan adanya kepahlawanan dan kedermawanan dari sosok yang memiliki identitas kelas kaya. Pembacaan oposisi biner yang muncul dalam dua kelompok (karakter) menunjukkan identitas Ibu Sulastri 
dan Pemberi Hadiah misterius sebagai golongan orang berkelas"kaya" dan sosok yang dermawan (pahlawan). Sementara itu, Ibu Rini Nurhayati dan Ibu Puji Rahayu menggambarkan identitasnya sebagai kelompok lemah, miskin, dan berhak membutuhkan pertolongan. Namun, adanya perubahan identitas semu (palsu) yang muncul ketika Ibu Rini Nurhayati mendapatkan hadiah dan seakan terjawab permasalahannya sehingga dapat meningkatkan ekonomi dan statusnya dari yang kekurangan (miskin) memiliki perubahan. Identitas yang berubah tersebut merupakan identitas ganda.

Kellner (2010:330) mengungkapkan identitas tersebut sebagai identitas ganda yang menandakan kepalsuan identitas, bahwa identitas dibentuk, bukan terberi, bahwa ia merupakan pilihan, gaya, dan perilaku daripada kualitas moral atau kualitas psikologis.

Program reality TV tersebut juga memberikesanbahwaidentitasadalahpermainan yang dimainkan seseorang dan dengan mudah seseorang mengganti identitasnya. Oleh karena itu, oposisi biner tersebut telah menunjukkan adanya identitas yang dilabelkan pada tiap-tiap tokoh karakter yang pada akhirnya penonton dapat menetapkan adanya si "kaya" yang dermawan sebagai pahlawan dan si "miskin" yang mendapatkan pertolongan. Penggambaran adegan di sebuah kota besar juga menunjukkan identitas-identitas masyarakat perkotaan yang memiliki perbedaan drastis antara yang kaya dan yang miskin. Masalah-masalah kaum miskin di perkotaan dipertontonkan melalui tokoh Ibu Rini Nurhayati dan Ibu Puji Rahayu. Sosok kaya dan dermawan yang seakan mewakili kelompok kaya perkotaan yang menjadi pahlawan dengan kedermawanannya. Kisah ini mengesankan betapa hebatnya kelompokkelompok kaya perkotaan yang dermawan dan dielukan sebagai pahlawan bagi kaum miskin di sekitarnya (perkotaaan). Peran mereka seakan mampu membuat perubahan identitas bagi kaum miskin pada identitas yang lebih (kelas menengah) dengan pemberian hadiah yang dianggap memberikan perubahan hidup dan menyelesaikan masalah-masalah mereka, yang sebenarnya belum mampu menyelesaikan.

\section{SIMPULAN}

Narasi yang dikerjakan di dalam program reality TV PM dapat dilihat melalui pembahasan oposisi biner (Levi Strauss). Hasil yang didapat atas pembacaan oposisi biner melalui konsep pembacaan sintagmatik dan paradigmatik dapat disimpulkan adanya perbedaan mendasar kelompok di dalam karakter-karakter yang muncul dalam reality TV PM. Adanya relasi dari miteme-miteme yang selanjutnya dibaca terdapat perbedaan yang muncul. Perbedaan tersebut dapat dikelompokkan menjadi dua kelompok, yaitu kelompok pahlawan (hero) dan yang ditolong (diberi bantuan/hadiah). Perbedaan dalam pengelompokan tersebut menjadi oposisi biner yang terbaca secara eksplisit dalam tayangan. Namun, dalam pembacaan selanjutnya, perbedaan (oposisi biner) yang terbaca adalah adanya kelompok kaya (pemberi hadiah) dan kelompok miskin (penerima hadiah), sebagai kelompok subjek yang menggerakkan narasi dan objek bagian dari narasi. Pembacaan ini tentang struktur dalam program reality TV PM, yaitu pahlawan dan yang ditolong bukan menjadi gambaran sebenarnya. "Struktur dalam" yang ada pada program reality TV PM lebih pada penggunaan orang-orang yang mengalami kesulitan ekonomi, yang tidak memiliki aset produksi sendiri (miskin) menjadi objek yang menggerakkan narasi. Narasi bekerja karena 
adanya objek. Subjek hanyalah penggerak yang menghubungkan dari awal hingga akhir dan memiliki kepentingan dan tujuan (visi) yang lebih jauh, yaitu keberhasilan sebuah tayangan program (menarik, punya nilai) sesuai rencana dari pembuat narasi (reality TV PM). Oleh karenanya dari hasil pembacaan oposisi biner, terjawab tentang narasi apa yang diciptakan oleh program reality TV PM, yaitu kekuatan (kaya) yang menjadikan objek (miskin) bagian yang menggerakkan narasi dalam reality $\mathrm{TV}$ PM.

Pada akhirnya, melalui pembacaan oposisi biner telah tergambarkan adanya kelompok yang berlawananan. Kelompok kaya dan miskin, kuat (pahlawan) dan lemah (yang ditolong), subjek dan objek. Oposisi tersebut menunjukkan adanya identitas dari masingmasing karakter yang dibentuk di dalam reality TV PM melalui penceritaaan narasinya. Melalui bangunan struktur narasi dan tokoh karakter-karakter di dalamnya. Selanjutnya, oposisi biner tersebut mampu menggambarkan struktur dalam yang dibaca adanya tema kemiskinan yang muncul secara implisit dan ditranskodekan melalui bangunan struktur narasi dan tokoh karakter di dalam program reality TV PM tersebut.

Sebuah teks narasi tidak akan terpisahkan dari struktur narasi yang dibangun di dalam narasinya. Bangunan strukur narasi tersebut sebagai cara menampilkan "apa cerita" yang dinarasikan dan "bagaimana" cerita tersebut dinarasikan. Gagasan awal narasi (reality TV PM) bagi pembuat narasi adalah ingin memberikan hadiah kepada orang yang memenuhi kriteria (mau membantu dengan ikhlas). Kriteria yang merupakan syarat bagi siapa saja yang berhak mendapatkan hadiah (uang dan barang). Pengembangan cerita yang dinarasikan melalui sosok Ibu Sulastri yang (alih-alih) mencari orang yang bersedia membantunya dengan mendorong kursi rodanya untuk mengantar ke rumah sakit dan memberikan bantuan kepada orang yang (dianggap) membutuhkan bantuan (Ibu Puji Rahayu). Kemunculan sosok Ibu Sulastri yang dermawan telah melabelkan identitas golongan yang mampu (kaya) memiliki kebaikan hati (pahlawan) yang membantu orang lain. Kemudian adanya tokoh Pemberi Hadiah Misterius juga menjadi citra identitas kelompok dermawan (pahlawan) bersama Ibu Sulastri. Kedua sosok karakter tersebut merupakan identitas yang paling stabil dan tetap dalam program reality TV tersebut. Kedua sosok tersebut digambarkan sebagai sosok yang memiliki kekuatan sebagai pahlawan yang membantu orang lain. Pelabelan identitas Ibu Sulastri dan Pemberi Hadiah Misterius terjadi secara alami dalam bangunan struktur narasi ditandai dengan munculnya tokoh-tokoh lain (Ibu Rini Nurhayati dan Ibu Puji Rahayu) sebagai penerima hadiah. Kehadiran kelompok penerima hadiah tersebut memberikan penggambaran dua sisi yang berbeda antara yang dermawan (pahlawan/kuat) dan orang yang membutuhkan bantuan (yang ditolong/ lemah). Posisi tersebut menjadi dua sisi berbeda (oposisi biner) dalam fungsi dan karakter narasi. Sehingga masing-masing posisi tersebut secara tidak langsung saling melabelkan sisi yang berbeda. Pelabelan yang diterima secara alami seiring bergeraknya sebuah narasi dari penceritaan awal hingga akhir telah membentuk sebuah wacana yang tanpa disadari penonton tentang kebaikan dan kedermawanan orangorang yang dianggap lebih mapan (kaya). Sebaliknya, adanya citra yang menunjukkan sosok lemah dan bermasalah ekonomi melalui 
penokohan Ibu Rini Nurhayati dan Ibu Puji Rahayu. Kekuatan lain yang dibangun dalam struktur narasi adalah adanya peran narator (internal/dramatis dan eksternal/non-dramatis) yang menguatkan informasi dan penegasan dua posisi yang bebeda dari pemberi hadiah dan penerima hadiah. Melalui alur cerita sedemikian rupa, reality TV PM yang hybrid mampu menggambarkan cerita yang mengalir dan diterima penonton tanpa disadari adanya pergulatan sosial yang termuat di dalamnya.

Dari pencitraan melaui reality TV PM, cerita yang dinarasikan telah mentranskodekan tema kemiskinan melalui bangunan struktur narasi, dimana bangunan tersebut menarasikan kepahlawanan, kedermawanan, subjek, kaya dan adanya pihak yang ditolong, yang lemah, miskin dan sebagai objek dalam program. Tema kemiskinan telah ditranskodekan melalui hadirnya sosok-sosok aktor dalam karakter dan fungsinya yang pada akhirnya menggambarkan adanya oposisi biner diantaranya. Oposisi biner tersebut dapat membaca adanya identitasidentitas yang akhirnya nyata nampak dalam citra. Namun, secara implisit identitas tersebut telah memamerkan adanya tema kemiskinan yang ditranskodekan melalui sosok-sosok karakter dan bangunan struktur narasinya. Tema kemiskinan muncul secara implisit sebagai bagian struktur dalam yang tidak dapat dibaca langsung melalui citra, namun telah melekat dan ditranskodekan melalui kehadiran sosok karakter yang saling berlawanan dan sebagai objek di dalam program reality TV PM.

Akhirnya dapat secara jelas terlihat bahwa tema dalam program reality TV PM yang menunjukkan adanya jiwa penolong, kedermawanan, sifat-sifat baik seseorang yang mau membantu orang lain yang membutuhkan dan lemah tidaklah lain hanya makna permukaan saja yang dicitrakan. Namun, secara mendalam orang-orang lemah yang ditolong hanya bagian dari objek yang menggerakkan sebuah program. Kehadiran mereka dibutuhkan untuk melangengkan identitas para penolong yang dermawan dan baik hati. Kehadiran mereka menjadi bagian utama yang harus ada untuk mmberikan sebuah nilai rasa simpati dan penonton. Tanpa disadari mereka hanyalah objek yang digerakkan untuk mendapatkan keutungan dan kepentingan sebuah industri melalui program reality $\mathrm{TV}$.

\section{KEPUSTAKAAN}

Bal, Mieke. 1997. Narratology (Introduction to The Theory of Narrative). Second Edition. Toronto: University of Toronto Press.

Barker, Chris. 2008. Cultural Studies. Teori dan Praktik .Diterjemahkan oleh Nurhadi. Kreasi Wacana.

Casey, Bernadette et al. 2002. Television Studies (The Key Concepts). Routledge: London and New York,

Eriyanto. 2013. Analisis Naratif: Dasar-dasar dan Penerapannya dalam Analisis Teks Berita Media. Yogyakarta: Kencana Prenada Media Group.

Fludernick, Monica. 2009. An Introduction to Narratology. Routledge: London and New York.

Herman, Luc \& Bart Vervaeck. 2005. Handbook of Narrative Analysis. University of Nebraska Press: Lincoln and London.

Hill, Annette. 2005. Reality TV, Audiences and Popular Factual Television. Routledge, London and New York.

Kellner, Douglas M. \& Meenakshi Gigi Durham. 2006. Media and Cultural Studies (Keyworks). Revised edition. Blackwell Publishing.

Kilborn, Richard. 2003. Staging the Real: Factual TV Programmingin the Age of Big Brother. Manchester: Manchester University Press. 
Pratista, Himawan. 2008. Memahami Film. Yogyakarta: Homerian Pustaka.

Prince, Gerald. 2003. Dictionary of Narratology. Revised Edition. Lincoln \& London: University of Nebraska.

Ahimsa-Putra,Heddy Shri. 2001. Strukturalisme Levi Strauss: Mitos dan Karya Sastra. Yogyakarta: Galang Press, hlm 40-41, dalam Eriyanto. 2013. Analisis Naratif, Dasar-Dasar dan Penerapannya dalam Analisis Teks Berita. Yogyakarta: Kencana Prenada Media Grup.

Stam, Robert. 1992. New Vocabularies in Film Semiotics, Structuralism, PostStructuralism and Beyond. London and New York: Routledge.

Stok, Jane. 2007. How to Do Media and Cultural Studies. Panduan untuk Melaksanakan Penelitian dalam Kajian Media dan Budaya. Diterjemahkan oleh Santi Indra Astuti. Yogyakarta: Bentang Budaya Pustaka. 
